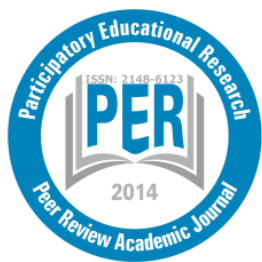

Participatory Educational Research (PER)

Vol. 6(2), pp. 122-143, December, 2019

Available online at http://www.perjournal.com

ISSN: 2148-6123

http://dx.doi.org/10.17275/per.19.17.6.2

\title{
Analysis of the influence of outdoor education activities on seventh grade students
}

\author{
Erol TAȘ \\ Ordu University Department of Science Education, Ordu, Turkey \\ https://orcid.org/0000-0003-4077-7351
}

Salih GÜLEN*

Muş Alparslan University Department of Child Development, Muş, Turkey https://orcid.org/0000-0001-5092-0495

Article history

Received:

02.09.2019

It is thought that the results of teaching some of the subjects in science through outdoor education will be more positive. The purpose of this study is to find out the effects of activities done through outdoor

Received in revised form: education on students' academic achievement, students' thoughts about 07.11.2019 the activities and the permanence of information. Mixed research design was used in the study. Academic achievement test was prepared

Accepted:

11.11.2019 to collect quantitative data while a test consisting of open-ended questions in fully structured interview form was prepared for qualitative

Key words: data. For the analysis of quantitative data, statistical analysis techniques

Achievement; Friendship; Outdoor education; Permanence; Students' such as average, frequency, percentage, standard deviation and Wilcoxon signed ranks test were used with the help of SPSS program. In qualitative analysis, the data were coded, common themes were thoughts formed with their categories and content analysis method was used. According to the results, it was found that outdoor activities increased students' achievement and did not have a significant relationship with students' recalling information. The results of the qualitative analysis showed that the students liked these activities and the activities were effective in understanding the subject and learning the concepts. In addition, it was found that the activities influenced the friendship between students positively. It was suggested for outdoor activities to be used in science teaching.

\section{Introduction}

Sciences can be addressed not only as an arena of research and thinking which is based on experimental criteria, logical thinking and continuous questioning, but also as a areas that try to define and explain nature. Thus, the purpose of sciences can be specified as realizing the mutual interaction of the individual and the environment as well as the society, adapting scientific processing skills and a scientific research approach and finding solutions to the problems encountered alongside developing curiosity, attitude and interest towards the phenomena that occur in nature (Ministry of National Education (MoNE), 2018). The most effective way of learning for students is learning through experience as a result of focusing on 
the subject and reviewing their experiences and activities (Stana and Humberstonea, 2011). Hence, the greatest advantage of outdoor teaching activities is giving the students a creative experience which they cannot forget about for a long time by increasing their ecological literacy and awareness (Balgopala and Wallaceb, 2009; Mukhopadhyay, Datta and Banerjee, 2014; Nicolson, 2019).

Outdoor education activities; are known as activities that take children out of classes and enable learning in a natural environment. These activities are experimental, open air learning methods based on interdisciplinary curriculum which require the use of all senses involving humans and natural resources. It is an effective method which enables students to learn a subject more permanently and to bear more positive feelings towards both nature and to their friends (Farmer, Knapp, and Benton, 2007). When compared with learning inside the classroom, it is a less structured form of education with a rich curriculum that develops automatically and in which elements of surprising nature can also develop (Lai, Chang, Shiane, Fan and Wu, 2013; Öztürk, 2009; Ramadoss and Poya-moli, 2011). Outdoor education focuses on the relationship between nature and individual. It provides the basis for the integration of the individual with nature and learning activities. It enables the individual to use many disciplines in a natural environment and also facilitates the use of interdisciplinary curricula (Uhls et al., 2014). Outdoor education simply takes place outside the school. The individual can use all sense organs in this educational process. In fact, this increases the permanence of learning. It is also an experimental method for learning outdoor training (Priest, 2010). Through this method, students learn many objects and events by experience. There are activities outside the classroom within the framework of outdoor education. A specific plan and program are available. In other words, certain gains are obtained as a result of the activity (Donaldson and Donaldson, 2013; Guardino, Hall, Largo-Wight, and Hubbuch, 2019). There are also unplanned trainings as part of this education. For example, parents' nature trips with their children and the learning that took place on this trip can be seen as unplanned learning.

For outdoor education, first of all, an outdoor environment should be chosen in which students will feel comfortable and thus can gain the necessary attainment (Neill 2008; Priest, 1986). Necessary precautions should be taken for students to participate in activities as well. During this practice, experiential activities are carried out through the use of real objects by using the five senses (Brookes, 2003). Students can understand the association between phenomena and knowledge through observation and can define the relationship between objects and phenomena instead of memorizing data/input. In outdoor education, activities can be interpreted as (more) interesting and fun by individuals since the environment is different from a patterned classroom environment (Lappin, 1997; Tsai, 2006). In addition, these activities are conducted so as to be able to make students develop environment protection oriented attitudes towards preserving nature by being aware of the wild and natural life (Berberoğlu and Uygun, 2013; Stanišića and Maksića, 2014).

Basically, it is aimed to gain knowledge or skills permanently through outdoor education. In addition to these goals, it is intended to achieve some gains in the group established with friends (Kida, 2019). Learning to work together harmoniously while having fun, applying cooperative strategies and techniques, learning to share roles and responsibilities, time and risk management in a multivariate and unknown environment, learning to act together, discovering new thinking and communicating methods, pushing limits, uncovering unknown abilities achievements such as being respectful to other individuals, understanding the importance of personal differences, learning to work efficiently under intense stress when 
necessary (Kinsman, 2019; Fox, 1950) are amongst the potential advantages. It is also known that friend relations increase socialization. In order to achieve a positive return, the group needs to work together towards actions such as planning, participation, problem solving, decision making and, where necessary, creating and maintaining leadership. The basis is effective team building. The skills needed in outdoor education are in parallel with the work and private life and the applied learning process can be reflected in those belonging to learners' future. Teamwork in outdoor education also affects the individual's personal development enhancing trust, feedback and dialogue along with questioning, communication, risk-taking skills (Bølling, Pfister, Mygind, and Nielsen, 2019; Rauch, 2019).

The importance of outdoor education is emerging for many reasons such as the boringness of the city life, the monotony of the modern world and the students' generally being away from the nature. Additionally, it is also important for students to see the functioning of nature in place. It is possible to come across many studies on outdoor education (Adams and Savahl, 2017; Askerlund and Almers, 2016; Bennett, 2019; Knight, 2018; Povilaitis et al., 2019; Remington and Legge, 2017; Ritzén, 2018; Sharma-Brymer, Brymer, Gray, and Davids, 2018; Thomas, 2015). Considering some of these; for instance, Hammarsten et al. (2019) share positive results in forest garden training with students at the age of 7 and 9. It was determined that students developed strong positive emotions about forest garden trainings, organized works, spontaneous activities and organisms living there. Outdoor education environments such as a forest garden provide students with information about the functioning of nature. Thomas (2019) confirmed that outdoor education provides the desired improvements in students' general life skills. Besides, it has been shown in the literature to be a facilitating learning style with outdoor training. Moreover, Huynh and Torquati (2019) discovered another aspect of outdoor training in their study: participants identified the health benefits of exposure to nature and found that they enjoyed mediating their relationships with nature through their work. They also found that outdoor education plays a very important role as a channel to facilitate others' relationship with nature also fostering any associated physical and mental health benefits. What is more, outdoor education is thought to have an effect on academic achievement and remembering the input obtained.

Outdoor education allows students to get to know nature and environment and to be educated in these environments. With such trainings, it is stated that positive development of students' sensory and cognitive aspects may take place efficiently. It is also known that different learning environments affect students (Becker, Lauterbach, Spengler, Dettweiler and Mess, 2017; Çetken, 2018) in a desired fashion. Also, according to Thomas (2019), outdoor education takes place in an active learning process with carefully arranged and placed activities and enables experimental learning with non-teacher fronted or teacher-centered instruction. These effects were observed as academic achievement (Smith, Gidlow and Steel, 2012). Together with these, Yaşin (2012) found that outdoor activities did not reach the target and did not receive enough attention. This study tested the likelihood of this situation. The aim of the planned activities is presented with the findings. In this research, the effect of outdoor education and activities on students was investigated.

\section{Purpose of the Study}

The purpose of the study is to find out the effects of activities done through outdoor education on students' academic success and to find out students' thoughts on these activities. To this end, answers were sought to the following questions: 
(1) According to the pre-post test results, is there any meaningfulness of the activities carried out with outdoor education on the academic achievement of the students in living things and life units?

(2) Is there any meaningfulness in terms of the effect of outdoor education on retention according to the post- permanence test results?

(3) What are students' thoughts on outdoor education?

(4) How would activities done through outdoor education be ranked in terms of being liked by the students?

\section{Importance of the Study}

The purpose of outdoor education is to enable students to connect to nature and attain gains in easy and fun ways. In this kind of education, not only formal but also informal attainments are important. Questioning how being educated in nature through games and activities influences academic attainment is also crucial, especially for science education. Furthermore, it is also essential to find out learner thoughts on the activities. The uses of all sensory organs in the environment and active participation in such activities have a positive effect on learning. In particular, introducing a subject related to nature with outdoor education facilitates effective learning. The fact that the environment of the school where the application is made is suitable for this educational activity boosts the chances of arriving at positive results. It is thought that this study will be an example for other schools. Similarly, it is believed that schools which are not suitable for outdoor activities taking into account their facilities are able to do these activities in the nearest suitable natural environment. Overall, this study is thought to be a model practice.

\section{Limitations of the Research}

The research took place in a village school in the Black Sea region. The study is limited to 19 students. Appropriate analysis tests were used to generalize this situation to the universe. The research was conducted with seventh graders and the study is limited only to "Living Things and Life" unit of the existing curriculum.

\section{Methodology}

This study used mixed research design. The nested pattern is preferred with a view to escalating the objectivity of the study through quantitative data (Glesne, 2013; Merriam, 2013). While one group of pre-post weak experimental design was used, qualitative research techniques such as interview were used to find out the students' thoughts on the activities conducted.

\section{Participants}

A homogeneous (analogous) sampling was used. The aim in the analogous sampling is to determine a state of a subset of small and similar features (Yıldırım and Şimşek, 2013). The study was conducted with 19 students attending 7th grade at a state school of 19 Mayis town of Samsun. The pilot study was conducted with the participation of 29 students. The socioeconomic levels of students are similar. Families of all students are farming. These families grow hazelnuts. 


\section{Data collection}

An academic achievement test and a fully structured interview form were referred to in order to conduct data. The academic achievement test was used as pre-test before the application to determine the readiness levels of the students. After the practice ended, the same instrument was used as post-test to observe the increase in students' attainment. The same test was performed once six weeks after the application to measure the level of recall of knowledge. In addition, the fully structured interview form was resorted to with the intention of finding out the effect of the activity conducted on the students.

\section{Preparing data collection tools}

Great care was taken to check the reliability and validity of the academic achievement test which was prepared to find out students' academic achievement. To this end, first of all, two academic experts of the subject and one teacher prepared question items based on attainments. Pilot study was conducted on 20 question (multiple choices) items for the necessary analyses. With the item analysis conducted at the end of the pilot study, the questions with very high item difficulty index $(p>0.9)$ and those with very low item difficulty index $(r<0.2)$ were excluded from the test, decreasing the number of questions to 14 . At the end of this analysis, the difficulty of the test was found as $\mathrm{p}=0.64$ (moderate difficulty), while the distinctiveness index of the test was found as $\mathrm{r}=0.52$ (high distinctiveness). In addition, Cronbach's Alpha reliability value of the test was found as 0.78 (high reliability) and Kuder, Richardson (KR20) value of the test was found as 0.76 (Büyüköztürk, 2009; Çepni, 2010).

In order to ensure the validity of the test, questions including attainments were prepared meticulously. Thus, the content validity of the test was assured. In addition to this, a table of specifications was prepared to determine the cognitive levels of test questions (Table 1).

Table 1. Table of Specifications

\begin{tabular}{|c|c|c|c|}
\hline \multirow{2}{*}{$\begin{array}{l}\text { Academic Achievement Test } \\
\text { Attainment }\end{array}$} & \multicolumn{2}{|c|}{ Steps of cognitive process } & \multirow[b]{2}{*}{ Total } \\
\hline & Remembering & Understanding & \\
\hline $\begin{array}{l}\text { 1. Can explain the concepts of species, habitat, population and } \\
\text { ecosystem with examples. }\end{array}$ & 1 & 2 & 3 \\
\hline $\begin{array}{l}\text { 2. Can explain the association of living organisms in an ecosystem } \\
\text { with each other and with non-living factors. }\end{array}$ & 1 & 2 & 3 \\
\hline $\begin{array}{l}\text { 3. Can make guesses about the living beings in different } \\
\text { ecosystems. }\end{array}$ & 0 & 2 & 2 \\
\hline $\begin{array}{l}\text { 4. Can compare the ecosystems in Turkey in terms of the variety of } \\
\text { living things and climatic features. }\end{array}$ & 0 & 2 & 2 \\
\hline $\begin{array}{l}\text { 5. Can realize the biological diversity in the ecosystem and } \\
\text { emphasize the significance of this. }\end{array}$ & 1 & 1 & 2 \\
\hline $\begin{array}{l}\text { 6. Can give examples of plants and animals in Turkey and the } \\
\text { world which have faced the danger of extinction }\end{array}$ & 1 & & 1 \\
\hline $\begin{array}{l}\text { 7. Can make suggestions about how to protect plants and animals in } \\
\text { Turkey and the world which are near extinction }\end{array}$ & 0 & 1 & 1 \\
\hline Note: Since the measurement tool was a multiple choice test, questio & ns were not a & & 14 \\
\hline
\end{tabular}

According to Table 1, 4 questions are remembering level. 10 questions are at the level of understanding. The questions were classified according to the renewed version of the Bloom's Taxonomy (Köğce, Aydın and Yıldız, 2009). The reason for not choosing the questions from the upper levels of the very taxonomy is that there is no subject gains from the upper levels.

The following two questions were asked in the fully structured interview form developed in 
order to find out what kind of an impact the subject of research had on students and to find out how much the activities were liked by the students:

1. Dear students, what are your thoughts about the activities we've conducted? (While answering this question, think about whether they helped you to understand the subject and whether you liked them or not and also write your reasons.)

2. Dear students, the activities we've carried out are listed below. Can you score these activities from 1 to 10 by using numbers according to your level of liking them? (You can give the same score to different activities and you can give very low or very high scores)

$\begin{array}{ll}\text { Number Activities } \\ 1 & \text { Warm up game } \\ 2 & \text { Collecting living beings } \\ 3 & \text { Water, food and shelter game } \\ 4 & \text { Food chain (Balance ring) } \\ 5 & \text { The game of changes in living beings } \\ 6 & \text { The generation is under threat (Drama) }\end{array}$

\section{Data Analysis}

SPSS and Microsoft Office Excel 2007 package programs were used for the analysis of quantitative data in the study. Since the necessary conditions for the practice of parametric tests were not met, one of the non-parametric tests, Wilcoxon signed ranks test was used (Çepni, 2010). Together with these, statistical analysis techniques such as average, frequency (f), percentage (\%) and standard deviation were used. Content analysis techniques were used for the analysis of the qualitative data. After the papers of all students were marked, the thoughts of the students about the activities were coded and categorized to create common themes with other students. The codes and categories specified were presented as Tables according to frequency of being used. As for the reliability of the study, the categories and common themes were specified by one teacher and two instructors (Yıldırım and Şimşek, 2013; Merriam, 2013). For the coding and scoring, the reliability was calculated using the formula of Miles and Huberman (1994). According to this calculation, $93 \%$ confidence coding was performed throughout the study. In fact, according to Miles and Huberman (1994), 80\% and above were accepted as reliable (Arık and Y1lmaz, 2017).

\section{Outdoor Education Plan}

The plan shared in detail below was followed. Before the start of the activity, the teacher talked with the students to set the necessary rules and emphasized the important points.

Specifying the place and restricting the area: For outdoor activities, the woods close to our school garden which fit our purpose were chosen not to experience time problems and not to step out of the framework of legal permission. Luckily, the school is surrounded by many different types of trees, hazelnut trees in the first place, and has sufficient amounts of greenery. In terms of educational games and drama activities, the school garden and the empty land beside the school campus were made use of. The activity area was specified before the research and the students were informed not to go beyond the specified place for security purposes.

Preparing a sketch: Help was taken from the Social Sciences teacher of the school for the sketch of the activity area. In addition, Google Earth program was used. Each student was given a sketch and told how to use it. The sketch given as example in Figure 1 belongs to the second group of students. As can be seen in the example, the students specified the places of the living beings they collected during the relevant activity by signing them at the sketch. 
Thusly, they learned how to use a sketch. In addition to sketch, they used a compass in order to determine the necessary directions.

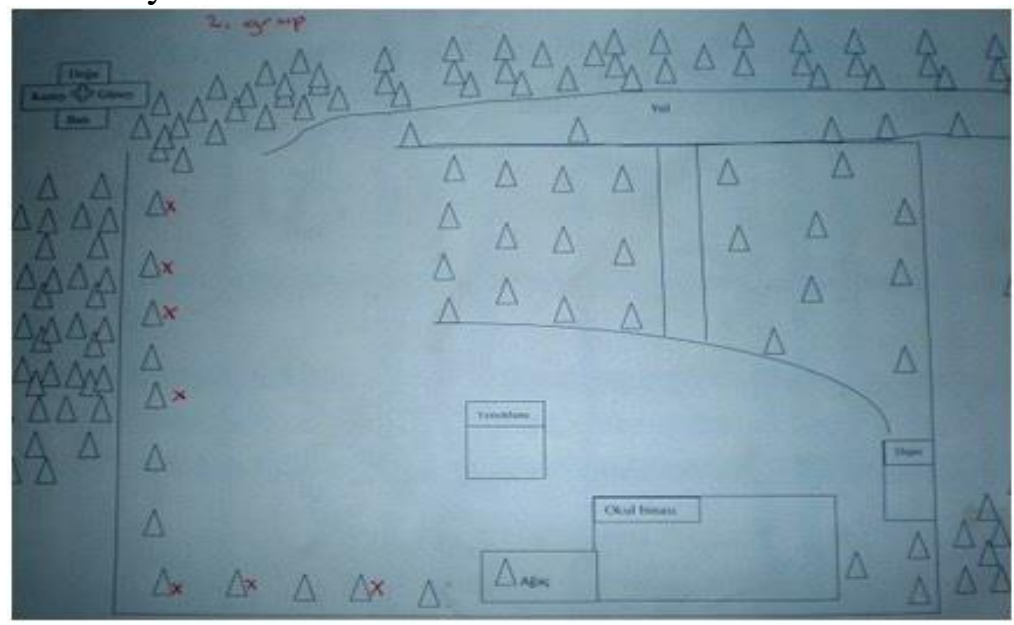

Figure 1. Sketch sample prepared by students

Preparing the necessary equipment for activities: Students' learning about how to use a compass and sketch, and how to use containers, how to use a magnifying glass for the analysis of the living beings samples (leaves of similar and different sorts, insects, worms, and so on) could be seen as informal attainments and necessary precautions were taken to make the students gain these attainments as desired. The sketch, compass, container, magnifying glass to be used in these activities and the sheet on which the students will examine the living beings collected were provided beforehand for the students by the researcher.

Warm up activity: An activity of passing the ball was planned for the students to get to know each other before the actual activities started. This activity is ideal for groups who do not know each other well. The game ends with the first starter to come to the front after passing the ball over and under the shoulder (Pictures 1 and 2).

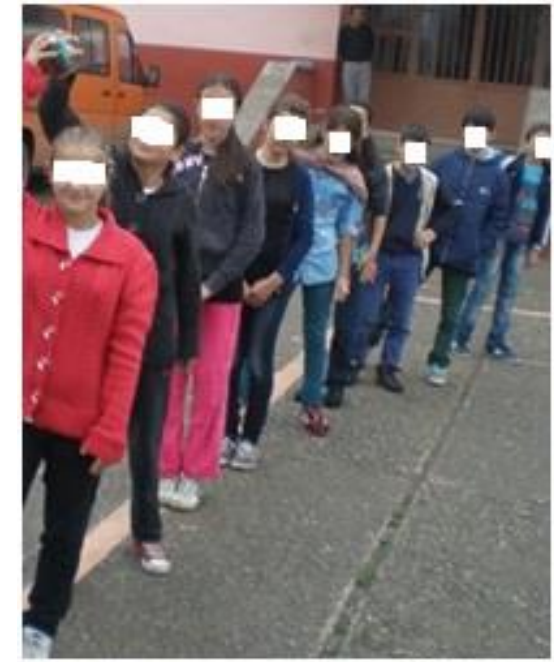

Picture 1. 1st group preparing for the warm up activity

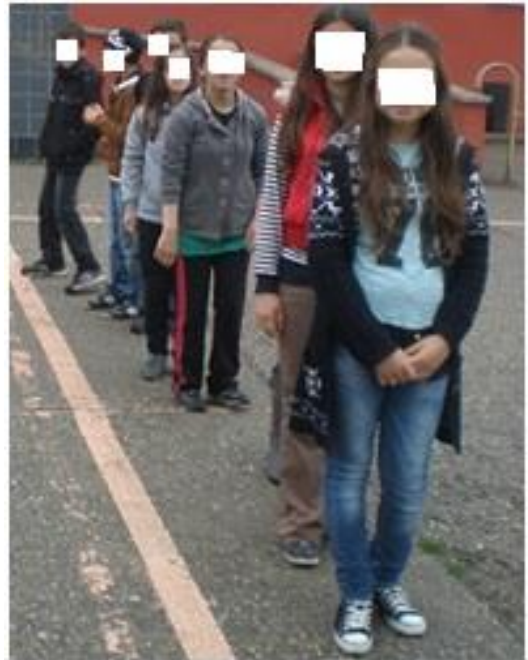

Picture 2. 2nd group preparing for the warm up activity

Collecting living beings: This is one of the most important activities for the students to learn the concepts about the subject. Before they start the activity, the students form a circle and the 
teacher determines the groups (Picture 3). At this stage, it is important for the group to be made of compatible members who can get along with each other. The teacher knows the students before the activity and forming the group accordingly is helpful for the research to reach its purpose.

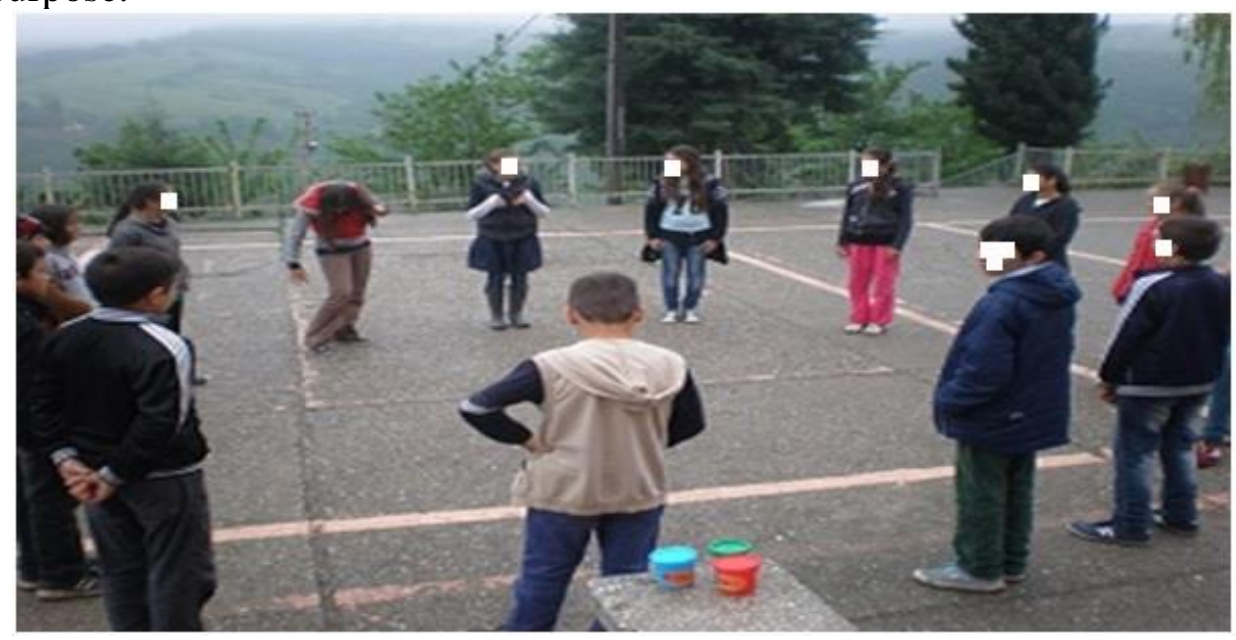

Picture 3. The circle students made in order to form a group

The sketch of the area previously distributed to students and different missions were given to different groups. The first group chose to collect leaves different from each other, while the second group chose to collect leaves of the same origin. Here, the students were told that they should not harm the trees and that the leaves on the ground had to be collected. While the third group chose the mission to catch the living beings such as insects, bees and butterflies in the area, the fourth group chose to collect worms. These groups were told not harm the animals while collecting them. In addition, each group was asked to sign the place where they collected living beings on the sketch. Here, it is also fundamental for the students not to be scared of these living beings and not to hurt them.

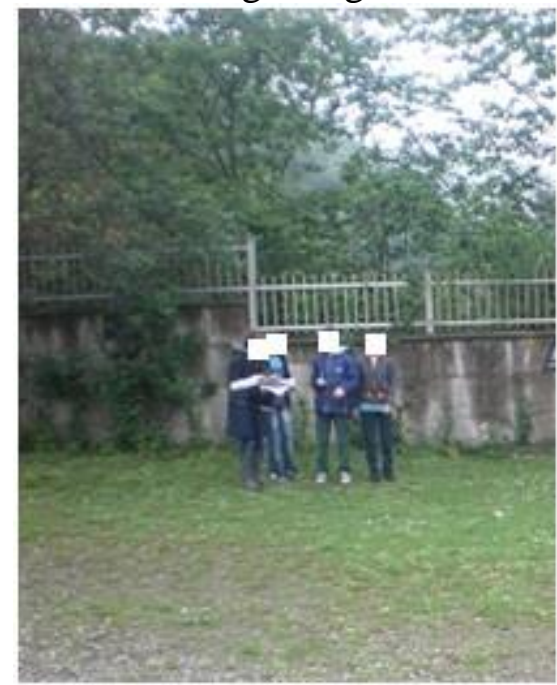

Picture 4. The group signing the sketch

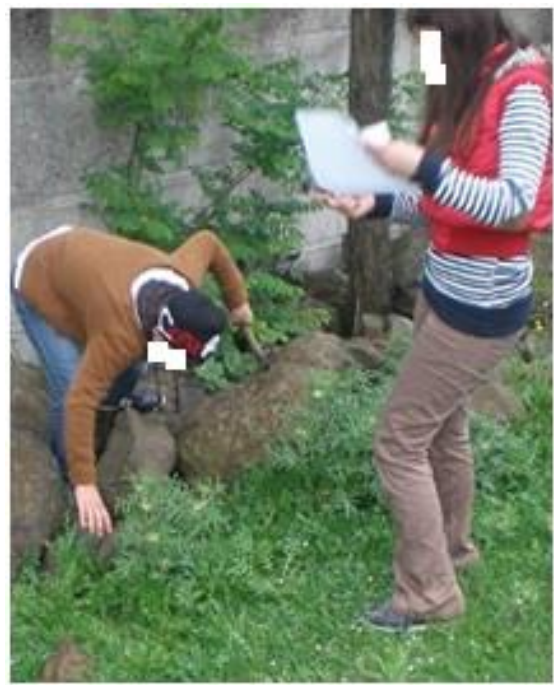

Picture 5. The group looking for worms

As can be seen in Picture 4, students sign the living beings they found on the sketch. Picture 5 shows the group looking for worms by digging the soil. Picture 6 shows a group who put a spider found into a container. The students did not close this container the organisms were just left there unharmed until the activity was finished. Picture 7 shows the worm in the soil to 
be put in the container with the soil. All these living beings were released into the natural environment when their mission was completed and none of them was harmed.

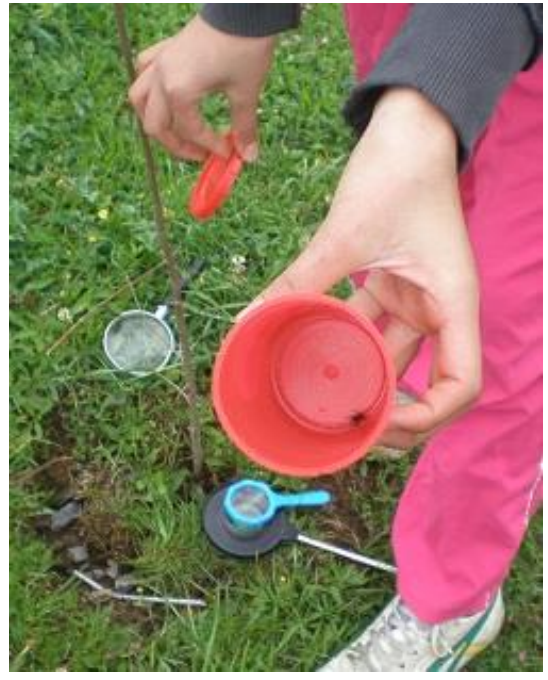

Picture 6. Students putting a spider in the container

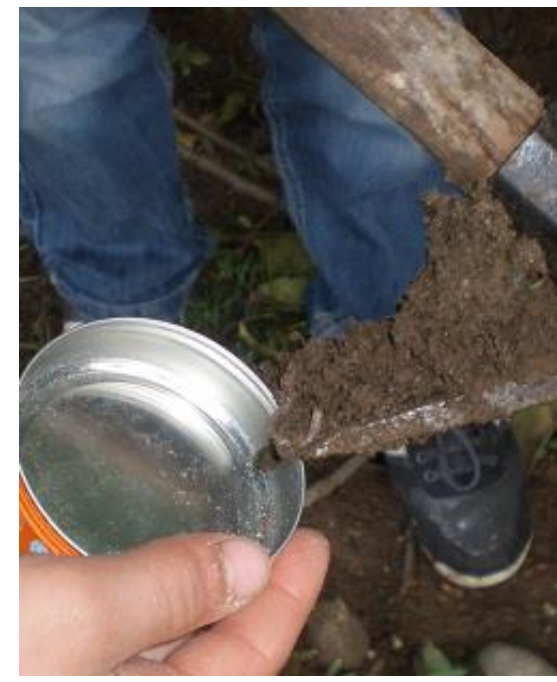

Picture 7. Students putting worms in the container

As can be seen in Pictures 8 and 9, all the living beings were put on the sheet laid on the ground. The teacher asked the students to analyze these living beings by using magnifying glasses. The teacher also asked various questions to the students based upon the characteristics of living beings. The concepts of species, population, habitat and ecosystem were explored by the students.

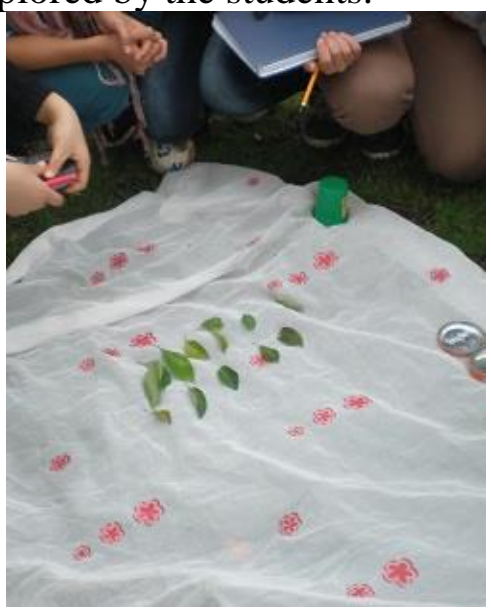

Picture 8. Different leaves collected

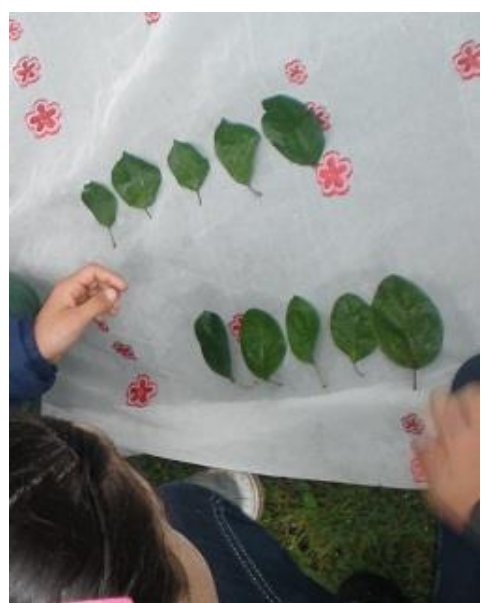

Picture 9. Same leaves collected

In general, the students were asked to find out the differences and similarities between living beings, to make comments on the habitat of living beings and to guess the characteristics of the living and non-living beings in these places. Definitional expressions were given by the teachers and the students were made to make comments about the characteristics of these expressions. Here, the students gave a great number of different examples about the concepts of the subject.

Water, food and shelter: The purpose of this activity is to help the students comprehend the importance of the basic needs of living beings. The teacher told the meanings of the signs given in pictures below to students. Picture 10 shows the sign that represents "hunger", 
Picture 11 shows the sign that represents "thirst" and Picture 12 shows the sign that represents "shelter".

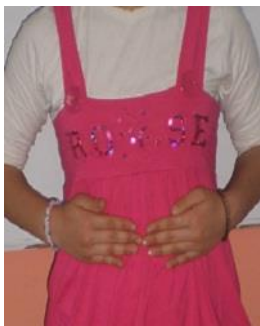

Picture 10. Hunger sign

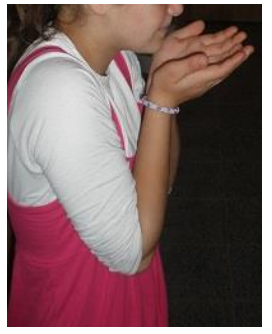

Picture 11. Thirst sign

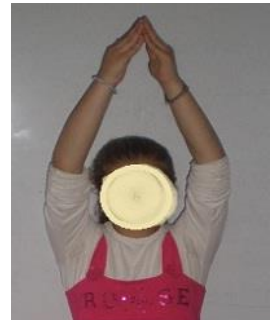

Picture 12. Shelter sign

The class was divided into two groups for the game and the groups were lined opposite each other as can be seen in Picture 13. The groups turned their backs to each other and picked up a sign. With the teacher's sign, groups turned round facing each other and went near their friends who made the same sign in the opposite group (Picture 14) to prevent from being eliminated. The students who were eliminated were taken out of the game. The game continued until the last two students were left.

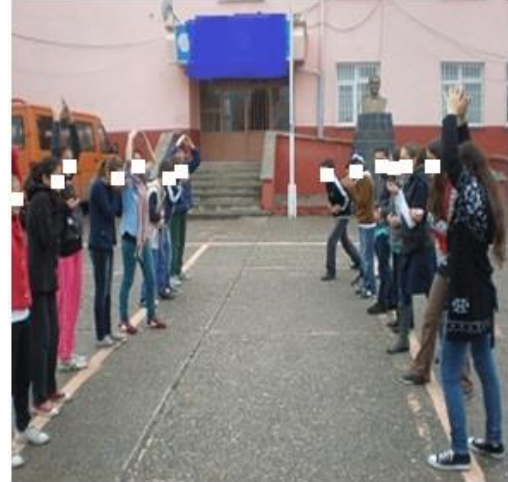

Picture 13. Students standing opposite each other for the game

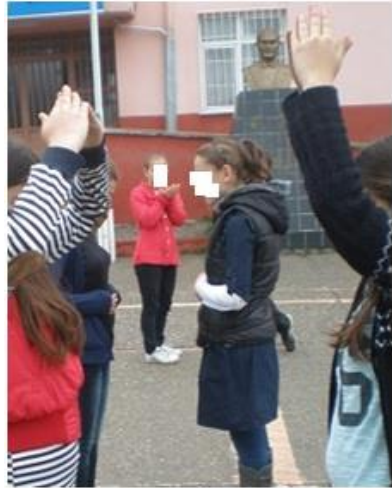

Picture 14. A photo from the game

Food chain: This activity represents the food chain in nature. The students come together by forming a circle and each student tries to keep the balance by sitting on the other student's knee (Pictures 15 and 16). With this activity, the students realized that the food chains in the ecosystem form a specific balance and that the balance will be disrupted through any interruption to this balance. Likewise, they expressed that factors such as overhunting and deterioration of their habitat disrupted this chain.

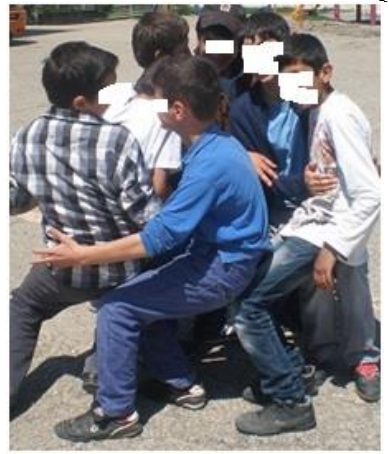

Picture 15. Food chain formed by male students

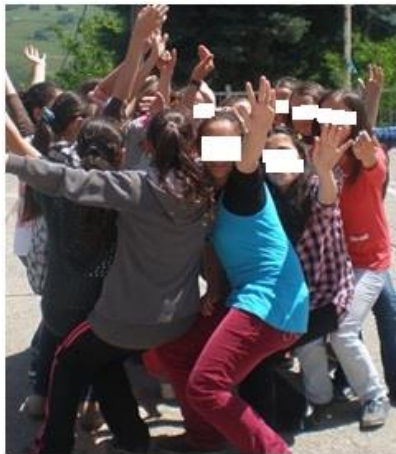

Picture 16. Food chain formed by female students 
The change in living beings: The purpose of this activity is to make the students comprehend the association between living beings and food and to make them realize that the living beings who find food in nature and who are strong can move to upper steps in food chain. The students were grouped in four. The first group represented "wheat" from green plants, the second group represented "sheep" from herbivores, the third group represented "wolf" from carnivores and the fourth group represented "eagle" from predatory. The students walk around the group by making the primary sign of the living being they represent, and they play the stone-paper-scissors game when they meet their own species (Picture 17). The student who wins the game passes to an upper class and becomes a member of the upper living being group by showing a biological change. Those who pass the last step of predatory become "human" and the game ends (Picture 18). At the end of this activity, the students comprehend the relationship among living beings in relation to food. In addition, they realize that the strong living beings in nature are in upper steps.

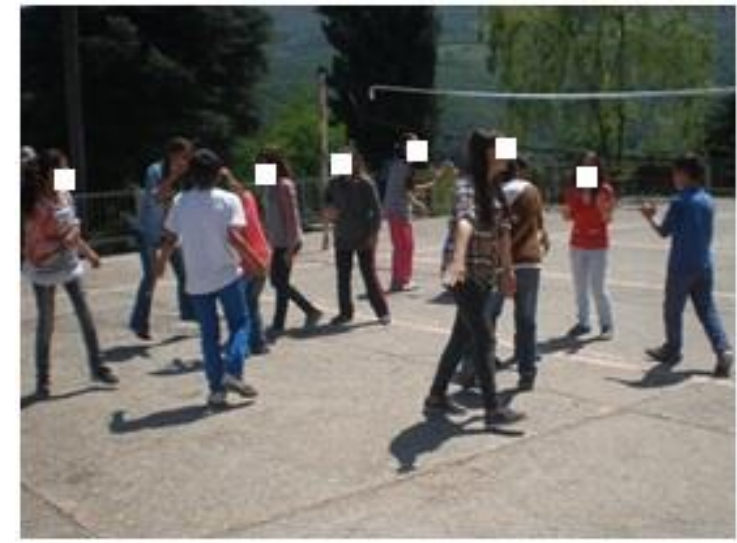

Picture 17. A photo from the activity

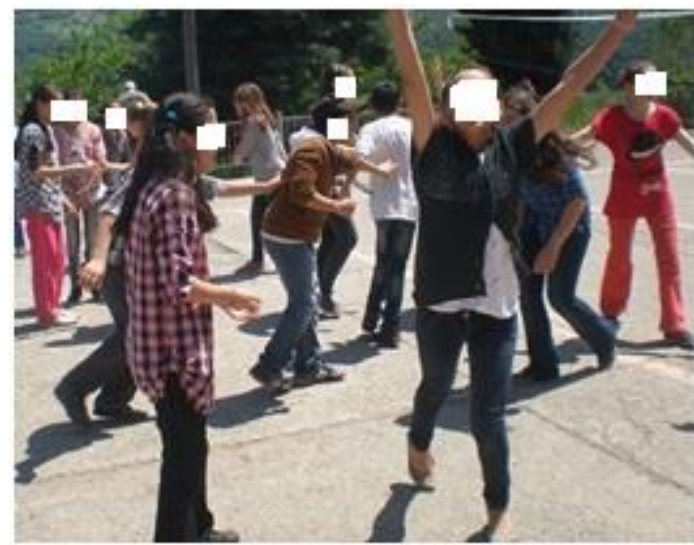

Picture 18. The student who passes all the steps

Species under threat: The purpose of this study is to make the students empathize with endangered living beings or living beings that are under the threat of extinction. With this purpose, the students formed four groups and prepared a creative drama by using previously prepared postcards. Postcards consisted of two living beings specific to the area the students lived in that were becoming extinct/extinct.

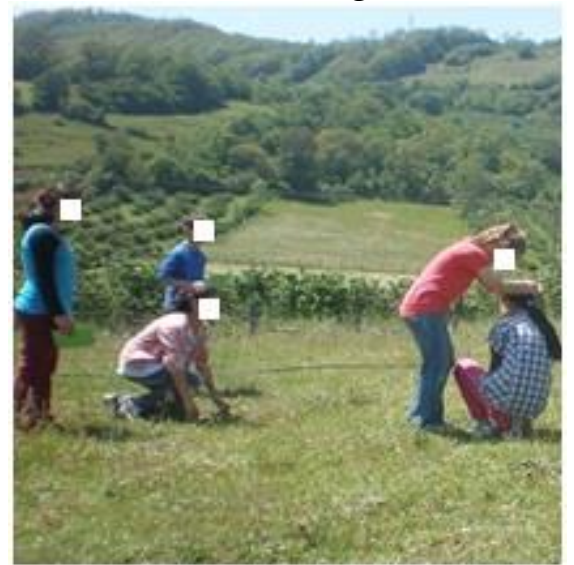

Picture 19. First group "Apollo Butterfly"

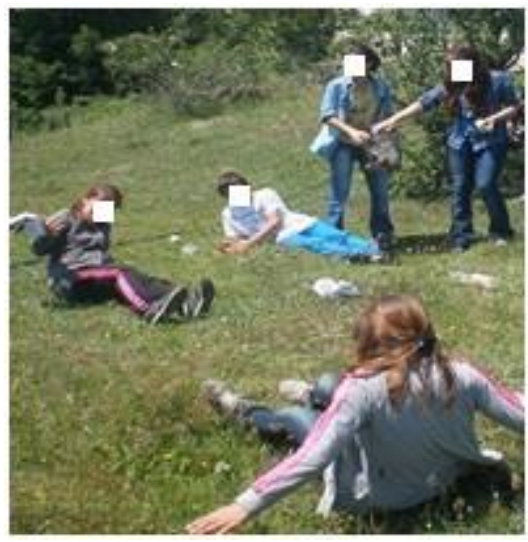

Picture 20. Second group "Mediterranean Seal" 


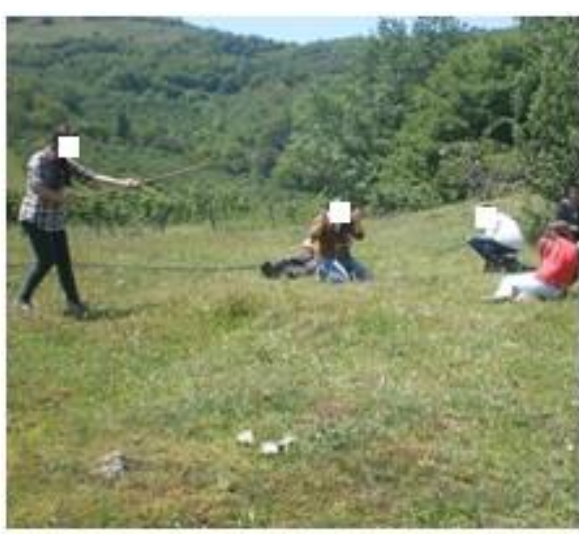

Picture 21. Third group "Rupicaprarupicapraornata"

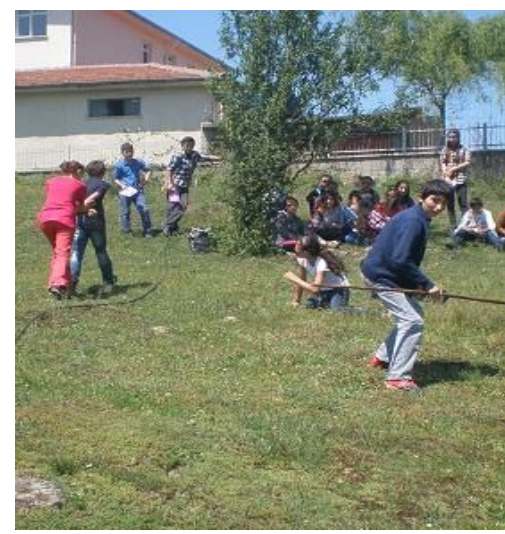

Picture 22. Fourth group "Anatolian Leopard"

The drama of the first group demonstrates the rescue of Apollo Butterfly, which is under the threat of extinction, by bees before it was eaten by wild flowers (Picture 19). The drama of the second group represents the struggle of a Mediterranean Seal, which is under the threat of extinction, to survive in contaminated (garbage and nuclear waste) water (Picture 20). The drama of the third group shares the unconscious hunting of Rupicaprarupicapraornata, which is under the threat of extinction, in highlands by hunters (Picture 21). The drama of the fourth group tells the killing of extinct Anatolian leopard by hunters and the capturing of the hunters (Picture 22). As can be understood from the dramas prepared on extinct species or species which are under the threat of extinction, the students comprehended the danger these living beings are in (Aytaş, 2013).

Table 2. The time recommended for the activities in outdoor plan

\begin{tabular}{ll}
\hline Steps of the plan & Time \\
\hline Pre- test & $40 \mathrm{~min}$ \\
1. Specifying the place, restricting and introducing the area & \\
2. Preparing and presenting the sketch & $40 \mathrm{~min}$ \\
3. Supplying and presenting the equipment & \\
4. Describing the activity rules & $30 \mathrm{~min}$ \\
5. Warm up & $40 \mathrm{~min}$ \\
6. Collecting living beings & $30 \mathrm{~min}$ \\
7. Water, food and shelter & $30 \mathrm{~min}$ \\
8. Food chain & $30 \mathrm{~min}$ \\
9. Change in living beings (Evolution) & $40 \mathrm{~min}$ \\
10. In danger of extinction & $40 \mathrm{~min}$ \\
Post Test & $40 \mathrm{~min}$ \\
Reflection & 9 hours of class time \\
Total &
\end{tabular}

Table 2 presents the times recommended for outdoor activities. The activities were finished within the times specified in the activity plan. The total time recommended for all the attainments of the unit is 16 hours of the class (Leblebicioğlu, 2012). In outdoor study, the goal was to make the students gain 7 attainments and the $56.25 \%$ ( 9 hours of class time) of this time was used in the activity.

\section{Results}

There are both qualitative and quantitative results of the study. These results are given below in detail. 
Quantitative results: The data obtained from the academic achievement test are given below. Table 3 presents the pre and post test statistical data of the study group.

Table 3. Comparative statistics of the groups

\begin{tabular}{llllll}
\hline Test & $\mathbf{N}$ & Average & Standard Division & Minimum & Maximum \\
\hline Pre test & 19 & 8.63 & 2.29 & 4.00 & 12.00 \\
Post test & 19 & 11.05 & 1.68 & 8.00 & 14.00 \\
Permanence & 14 & 9.60 & 2.15 & 6.00 & 14.00 \\
\hline
\end{tabular}

According to Table 3, the pretest average scores of students were 8.63 and the standard deviation were 2.29. According to the table 3 the posttest average scores of students was 11.05 and the standard deviation was 1.68. In addition, the permanence test average scores of students were 9.60 and the standard deviation were 2.15.

Table 4. Wilcoxon signed rank test results of pre-test and post-test scores

\begin{tabular}{llllll}
\hline Post Test - Pre Test & N & Rank average & Rank total & z & p \\
\hline Negative Rank & 1 & 2 & 2 & $-3.438^{*}$ & .001 \\
Positive Rank & 15 & 8.93 & 134 & & \\
Equal & 3 & & & & \\
\hline
\end{tabular}

* On the basis of positive ranks

The data in Table 4 are used to find out whether there was any difference between the students' scores from the pre-test and post-test of the multiple choice test and the learning approach used. The fact that the " $p$ " value here is ".001" and that the difference was positive is important for the study.

Table 5.Wilcoxon signed rank test results of pre-test and permanency test scores

\begin{tabular}{llllll}
\hline Post Test - Permanence & N & Rank Average & Rank Total & z & p \\
\hline Negative Rank & 7 & 6.36 & 44.5 & $-.436^{*}$ & .663 \\
Positive Rank & 5 & 6.70 & 33.5 & & \\
Equal & 2 & & & & \\
\hline
\end{tabular}

* On the basis of positive ranks

The data in Table 5 are used to find out whether there was difference between the students' scores from the permanence test and post-test of the multiple choice test. The fact that the " $p$ " value here is ".663" is important for the study. Class size is 19 students. Five students did not participate in the permanence test because of their being absent towards the end of the school year resulting from their parents' involvement in hazelnut production.

Qualitative results: The recorded answers of all students who participated in the study were analyzed to find out common themes and the students' thoughts about the activities were summarized below in Table 6 and Table 7. In Table 6, the students' thoughts about the activities based on the frequency of their being referred to were ranked and in Table 7, the students' thoughts about the activities were listed by taking into consideration the themes and the frequency of responding to the categories.

When the answers of all students who participated in the study were analyzed, no data was found about a student who expressed dislike for the activities or who thought the activities were not necessary. However, during the practice, few students expressed the parts they did not like in the activities. 
Table 6. Students' thoughts on activities and the frequency of use

\begin{tabular}{lc}
\hline Thoughts & Frequency of use \\
\hline I understood the subject better & 10 \\
I both had fun and learned & 10 \\
It's good to learn through games & 7 \\
It's good to learn through playing with my friends & 7 \\
Activities were very good & 6 \\
We should repeat the activities & 6 \\
I liked the activities very much & 5 \\
I loved the activities very much & 4 \\
I learned the characteristics of living beings & 4 \\
I learned the subject & 2 \\
\hline
\end{tabular}

As shown in Table 6, the students stated that they liked the activities. The most frequently used three expressions were "I understood the subject better", "I both had fun and learned" and "It's good to learn through games". Similarly, the least frequently used expressions were; "I liked the activities very much", "I learned the characteristics of living beings" and "I learned the subject". In addition, the results of the study showed apart from the main purposes of the study the activities influenced the students' feelings of friendship. At the end of the study, a significant number of students used expressions such as "It's good to learn through playing with my friends"

Table 7. Themes and categories determined from the answers of the students

\begin{tabular}{llc}
\hline Number & Themes and Categories & Frequency of use \\
\hline $\mathbf{1}$ & Students' attitudes towards activities & \\
$\mathbf{a}$ & Expressions of like & 25 \\
$\mathbf{b}$ & Disliked aspects of the activities & 7 \\
\hline $\mathbf{2}$ & The effects of activities on learning & 16 \\
$\mathbf{a}$ & Expressions showing that the subject was understood & 17 \\
$\mathbf{b}$ & Expressions showing that the subject was learned by having fun & 7 \\
$\mathbf{3}$ & The effects of the activities on friendship & 1 \\
$\mathbf{a}$ & Positive expressions that develop friendship & 7 \\
$\mathbf{b}$ & Negative expressions about friendship & \\
\hline
\end{tabular}

Table 7 shows the themes and categories determined through the analysis of students' answers to the open-ended questions asked at the end of the practice. According to the table, the students' answers to the questions were grouped under 3 themes. Apart from the first two themes determined for the purposes of the study, the third theme was determined coincidentally. These themes were explained with their categories by using the direct quotations of the students.

\section{Students' attitudes towards activities}

All the students who participated in the study (100\%) used positive expressions regarding the activities. The students expressed their likings and the delight they took in the activities as in the following activities.

I liked them very much because with these activities, I understood the subject very well and thus I can remember the lesson content (3rd student)

I loved these activities very much; I think that they were very useful (5th student) 
This activity made it quicker for me to understand the subject. Let's repeat such activities (9th student)

The activities we did were good for me (14th student)

They were all more fun and instructive than one another... (16th student)

I liked all of them, they were about the lesson, but they were fun. (17th student)

The explanations above show that the reasons such as "understanding" the subject better, "quicker" understanding of the subject, "fun" and "instructive" activities cause the students to "love" and "like" the activities. It is for sure that instructive and fun activities can increase students' level of understanding. The explanations above show that the students liked these activities. Besides these explanations, some students explained the disliked parts of the activities with the following expressions.

...there were just some disagreements within the group... (1st student)

...I didn't like the balance ring much; it was not very good because I could not keep the balance... (6th student)

...warm up game was not very necessary because the other activities were also like warmup games...(7th student)

...the game of changes in living beings was complicated; everybody became a human all of a sudden. If we had played it regularly and if its reasons were told and if the wheat had asked questions to sheep while getting transformed, it would have been better. (9th student) ...but it was a bit bad...some cheated during the third activity...(15th student)

The explanations above show that the students used negative expressions about the activities because of the "disagreements" within the groups, "not keeping balanced" at the balance ring, "complicated" nature of the game of changes in living beings, others" "cheating" during the games or "not wanting warm up activities" since all the activities ignited creation of social bonds. Setting rules previously and explaining these rules thoroughly are very important for the game to reach its purpose in instructive manners.

\section{The effects of activities on learning the subject}

A great number of students who participated in the practice stated that they understood the subjects better. Some of these students stated that activities helped them to understand the subject while some stated that they learned by having fun as in the following examples.

While doing these activities, I both had fun and learned a lot of things that I hadn't known.

This helped me a lot...(2nd student)

I understood better what ecosystem, species, habitat are...(3rd student)

Water, food and shelter game showed us how the living beings around struggle with life...(8th student)

...let's continue such activities. I didn't use to give straight answers to the teacher, my answers are now straight, because of this, I liked the activities...(9th student)

Food chain drama helped me because we got more information about the animals...(12th student)

I loved the subject ecosystems very much and I learned it well because no subject was so easy and fun... We learned getting joy out of it by playing a game...(18th student)

The explanations above show that the students learned the subjects they "did not know" before in a "better" way through "fun" activities and "games". As well as concepts such as "ecosystem", "population", "species" and "habitat", they also got more information about "animals". In addition, it can be understood that the students had clear information about the subject. Instructive activities seem to have significant levels of influence on understanding the subjects better and learning the concepts better. 


\title{
3. Effects of the activities on friendship
}

Although not in line with the purposes of our study, it was found that the activities positively influenced the friendship between students. The direct quotations of students on this theme are as follows.

\author{
...My friends and I had a lot of fun...(5th student) \\ ...I could understand the subject; it was useful, both for me and for my friends... I had a lot \\ of fun with my group (7th student) \\ It was good to play with my friends, to play with them while understanding the lesson \\ content (9th student) \\ ...I love playing with my friends because we had a lot of fun...(11th student) \\ I had a lot of fun with all my friends (13th student) \\ ...my friends and I helped each other when we fell down ...(15th student)
}

The explanations above show that the students think that playing "as a group" "with friends" and by "helping" each other is "fun" and "good". Thusly instructive games can be said to develop the feelings of friendship among students. In addition to these, one of the students was found to use a negative statement about friendship. This expression is below.

...there were some disagreements within the group (1st student).

The explanation above shows that the student had a "disagreement" with his "group". This point shows that while determining the groups, the harmony between groups should be taken into consideration by the teacher.

Table 8. Students' scores of the activities

\begin{tabular}{llc}
\hline Number & Activities & Score \\
\hline 1 & Water, food and shelter game & 184 \\
2 & Species under threat (Drama) & 178 \\
3 & Changes in living beings & 170 \\
4 & Collecting living beings & 157 \\
5 & Food chain (balance ring) & 155 \\
6 & Warm up game & 154 \\
\hline
\end{tabular}

Table 8 gives the list of the activities done by the students during the outdoor activity. The students were asked to score the activities between 1 and 10 according to how much they liked the activities (the activity that gets the highest score from all the students should have a score of $19 * 10=190)$. The three most liked activities by the students were "Water, Food and Shelter game", "Species under Threat (Drama)" and "Changes in Living Beings". In addition, even though it did not have a very low score, the "Warm up" game appeared as the last one on the list.

\section{Discussion}

The results of the analysis of the data from the study conducted are as follows.

According to Table 3, the average pre-test scores of the students were 8.63 while the standard deviation was 2.29 and the average post-test scores of the students were 11.05 while the standard deviation was 1.68. According to these results, it can be articulated that the students' average post-test scores increased when compared with the average post-test scores. Also, when the pre-test and post-test standard deviations were compared, it can be pinpointed that the scores of the students in the post-test were closer when compared with the pre-test. However, the significance between the post-test and pre-test scores of the multiple choice test 
was important for our study (Büyüköztürk, 2009). Wilcoxon signed ranks test results in Table 4 shows that there is a significant difference between the pre-test and post-test multiple choice test results of the sample $(z=3,289, p<0,05)$. When the rank total of difference scores is considered, it can be seen that this difference is in favor of ranks, that is, the post-test. These results show that outdoor education method caused changes in students. The outdoor education given in line with the purposes of our study seemingly increase the academic achievement of students. Similar to the findings of the study, Smith, Gidlow and Steel (2012) with Zwick and Miller (1996) found that students' academic achievement increased with outdoor education. Bølling, Pfister, Mygind, and Nielsen (2019) and Frauman (2011) stated in his study that outdoor education could be used in nurturing student satisfaction, responsibility for the environment and learning. In addition, it can be said that sustainability-literacy can be developed through learning that occurs as a result of these activities (Lugg, 2007).

According to the results of the permanence test conducted on students one month after the outdoor activities (Table 5), no significant difference was found between post test and permanence test results. The reason for this result may be on account of the fact that the the permanence test was given in the last week of the academic year and five students who took part in all the practices were not present on that day. Apart from these, the traditional last week syndrome (a decrease in students' interest, attitude and motivation towards the test or the lesson) might have influenced test results. Elliot and Trash (2001) and Singh Granville and Dika's (2002) study found that motivation and attitude were associated while Özkan and Pektaş's (2014) study found that interest was associated with student success. James and Williams (2017) emphasized that outdoor education is a prerequisite for learning rather than putting a test centered education into the centre. In addition, Churchill, Kennedy, Flint, and Cotton (2010) and Huynh and Torquati (2019) underscored that the educational practices of outdoor education provide a better understanding of the subject matter. However, it can be underlined that the level of remembering of knowledge is poor in the findings of this very study. Therefore, it can be accentuated that the subject is not learned very well.

According to the results of the qualitative data, it can be said that most of the students liked the outdoor activities and that the instructive and fun activities pertaining to the subject increased students' level of understanding and instructive activities and games were effective in understanding the subject and learning the concepts in a better manner. Tatar and Bağriyanık (2012) and Teyfur's (2008) studies show that outdoor activities are effective in increasing students' interests, curiosity and willingness. At the same time, Tatar and Bağriyanık's (2012) study exhibited that a great majority of teachers preferred outdoor activities for their students to learn by experiencing. In their studies, Ören Şaşmaz and Erduran Avc1 (2004) and Kaplan, Öztürk and Ertör (2013) found that instructive activities (for example, role play) increased students' success. Berberoğlu and Uygun (2013) and Çengelci (2013) stated that outdoor activities were necessary for understanding the subject well. These results are in line with the results of our study. In the analysis of qualitative data, it was found coincidentally that outdoor education influenced friendship among learners positively mainly owing to increased interaction between groups. Similarly, Efe, Oral, Efe and Sünkür (2011) and Karakaya (2011) noted in their studies that positive feelings could develop between group members who had cooperation and interaction. Smith, Gidlow, and Steel (2012) found that outdoor education had a positive impact on socialization. In addition, Allin and Humberstone (2006) and Rauch (2019) implied that outdoor education has a socio-cultural impact on individual career development. These data highlight that outdoor education affects different areas. 
As a result of the scores given to the activities between 1 and 10, the activities were ordered from the activity with the highest score to the activity with the lowest score. As can be seen from Table 8, considering that the highest score of the test is $19^{*} 10=190$, it can be said that all the activities were liked in general. In addition, the three most liked activities were "Water, Food and Shelter game", "Species under Threat (Drama)" and "Changes in Living Beings". The reasons why these activities were liked very much can be that science concepts could be adapted to daily life by making them more concrete, and the subject is structured in a fun way outside the school. In addition, although it did not get a very low score, "Warm up game" was in the last place. The reason for this may be the fact that since the other activities both explained the subject and enabled the students to play fun games, they were fancied more by the students than the warm up activity itself.

\section{Conclusion and Suggestions}

The academic success of the students seems to rise with the help of outdoor education. This success shows that the students understand the subject. Attention should be paid to the activities and types chosen here though. Use of outdoor education activity is recommended in science, especially while learning the subjects about the environment and nature; fun and creative games should be chosen accordingly in teaching the Living Things and Life Easier subjects. It is suggested that students' success in this subject will be increased especially if living things and life are carried out with an outdoor plan.

It was determined that outdoor education had no effect on keeping information in mind. This may be stemming from some problems with applications/execution. However, it should be ensured that the number of posttest and retention test participants is equal.

It is determined that outdoor education can add onto comprehension levels and that educational activities and games are instrumental in understanding the subject and learning the concepts. Outdoor activities are recommended to reiterate the importance of preventing the contamination of ecosystems in the world, to provide an increase in the number of environmentally literate people, and especially to provide primary and secondary school students with this awareness. Use of outdoor activities is recommended for students to recognize the existence and value of living beings around them by knowing their environment better. Outdoor education is also beneficial for students to grasp and ingternalize ecosystems and their relationships with them.

It was found out that educational game activities and drama activities were more popular as regards outdoor education. It was also randomly found that this education positively affected the friendship among the students. Similar activities should be planned in this theme because educational games apparently attract the attention of students. Outdoor activities are important for establishing and maintaining friendly relationships between student groups.

\section{Compliance with Ethical Standards:}

Funding: This study was not funded.

Ethical approval: All procedures performed in studies involving human participants were in accordance with the ethical standards of the institutional and/or national research committee and with the 1964 Helsinki declaration and its later amendments or comparable ethical standards.

Informed consent: Informed consent was obtained from all individual participants included in the study. 


\section{References}

Adams, S., \& Savahl, S. (2017). Nature as children's space: A systematic review. The Journal of Environmental Education, 48(5), 291-321.

Allin, L., \& Humberstone, B. (2006). Exploring career ship in outdoor education and the lives of women outdoor educators. Sport, Education and Society, 11 (2), 135-153. https://doi.org/10.1080/13573320600640678

Arık, S., \& Y1lmaz, M. (2017). Attitudes of science teachers towards environmental problems and their metaphorical perceptions for environmental pollution. Kastamonu Education Journal, 25(3), 1147-1164.

Askerlund, P., \& Almers, E. (2016). Forest gardens-new opportunities for urban children to understand and develop relationships with other organisms. Urban Forestry \& Urban Greening, 20, 187-197.

Aytaş, G. (2013). An alternative method in education and training: creative drama. Adlyaman University Journal of Social Sciences, 6(12), 35-54.

Balgopala, M. M., \& Wallaceb, A. M. (2009). Decisions and dilemmas: using writing to learn activities to increase ecological literacy. The Journal of Environmental Education, 40(3), 13-26.

Becker, C., Lauterbach, G., Spengler, S., Dettweiler, U., Mess, F. (2017). Effects of regular classes in outdoor education settings: a systematic review on students' learning, social and health dimensions. International Journal Environmental Research and Public Health, 14(5), 485-498. doi:10.3390/ijerph14050485

Bennett, T., (2019). Investigating the influence of gender, age, and camp type on the outcome achievements of children under 10 years of age at summer camp. Journal of Outdoor Recreation, Education, and Leadership, 11(3), https://doi.org/10.18666/JOREL-2019V11-I3-9202

Berberoğlu, E. O., \& Uygun, S. (2013). Examining the development of female education class in the world and in Turkey. Mersin University Education Faculty Journal, 9 (2), 3242.

Bølling, M., Pfister, G. U. Mygind, E., Nielsen, G. (2019). Education outside the classroom and pupils' social relations? A one-year quasi-experiment. International Journal of Educational Research, 94, 29-41. https://doi.org/10.1016/j.ijer.2019.02.014

Brookes, A. (2003). A critique of Neo-Hahnian outdoor education theory. Part two: "The fundamental attribution error" in contemporary outdoor education discourse. Journal for Adventure Education and Outdoor Learning, 3(2), 119-132.

Büyüköztürk, Ş. (2009). Manual of data analysis for social sciences. Ankara: Pegem Academy.

Churchill, D., Kennedy, D., Flint, D., \& Cotton, N. (2010). Using handhelds to support students' outdoor educational activities. International Journal of Continuing Engineering Education and Life Long Learning, 20(1), 54-71, DOI: 10.1504/IJCEELL.2010.031648

Çengelci, T. (2013). Opinions of social science teachers on non-classroom learning, Educational Sciences in Theory and Practice, 13(3), 1823-1841.

Çepni, S. (2010). Araştırma ve proje çalışmasına giriş (Introduction to research and project work). Trabzon: Celepler typography.

Çetken, H. Ş. (2018). An investigation of preschooler's play preferences regarding the design of outdoor play areas. Unpublished Master's Thesis, the Graduate School of Social Sciences of Middle East Technical University, Ankara 
Donaldson, G. W., \& Donaldson, L. E. (2013). Outdoor education a definition. Journal of Health, Physical Education, Recreation, 29(5), 17-63. https://doi.org/10.1080/00221473.1958.10630353

Efe, H. A., Oral, B., Efe, R., \& Sünkür, M. Ö. (2011). The effect of cooperative teaching method supported by computer simulations of photosynthesis unit on student access and biology lesson. Necatibey Education Faculty Electronic Science and Mathematics Education Journal, 5 (1), 313-329.

Elliot, A.J., \& Trash, T.M. (2001). Achievement goals and the hierarchical model of achievement motivation. Educational Psychology Review, 13 (2), 139-156.

Farmer, J., Knapp, D., \& Benton, G. M. (2007). An elementary school environmental education field trip: Long-term effects on ecological and environmental knowledge and attitude development. The Journal of Environmental Education, 38(3), 33-42.

Fox, D. C. (1950). The outdoor education curriculum at the elementary school level. The Journal of Educational Sociology, 23(9), 533-538, DOI: 10.2307/2263605

Frauman, E. (2011). Incorporating the concept of mindfulness in informal outdoor education settings. Journal of Experiential Education, 33(3), 225-238. https://doi.org/10.1177/105382590113300303

Glesne, C. (2013). Introduction to qualitative research (Translated by Ersoy, A., \&Yalçınoglu, P.). Ankara: Anı Publishing.

Guardino, C., Hall, K.W., Largo-Wight, E. \& Hubbuch, C. (2019). Teacher and student perceptions of an outdoor classroom. Journal of Outdoor and Environmental Education, 22(2), 113-126. https://doi.org/10.1007/s42322-019-00033-7

Hammarsten, M., Askerlund, P., Almers, E., Avery, H., \& Samuelsson, T. (2019). Developing ecological literacy in a forest garden: children's perspectives. Journal of Adventure Education and Outdoor Learning, 19(3), 227-241. https://doi.org/10.1080/14729679.2018.1517371

Huynh, T., \& Torquati, J.C. (2019). Outdoor adventure instructors' perceptions of nature and their work: a phenomenological study. Journal of Adventure Education and Outdoor Learning, 19(3), 269-282, https://doi.org/10.1080/14729679.2018.1531041

James, J. K., \& Williams, T. (2017). School-based experiential outdoor education: A neglected necessity. Journal of Experiential Education, 40 (1), 58-71. https://doi.org/10.1177/1053825916676190

Kaplan, A., Öztürk, M., \& Ertör, E. (2013). The efficiency of computer-aided instruction and creative drama on academic achievement in the teaching of integers to seventh grade students. International Journal of Academic Research, 5(2), 49-56.

Karakaya, Z. (2011). Social interaction and linguistic development in role plays. Journual of Gazi Education Faculty, 31(2), 419-438.

Kida, P. (2019). Competences and qualifications in outdoor education. The Journal of Education, Culture, and Society, 1, 79-92.

Kinsman, J. (2019). Understanding life in school: From academic classroom to outdoor education. Educational Philosophy and Theory, 51(5), 531-534. https://doi.org/10.1080/00131857.2018.1449462

Knight, S. (2018). Translating forest school: A response to Leather. Journal of Outdoor and Environmental Education, 21(19), https://doi.org/10.1007/s42322-017-0010-5

Köğce, D., Aydın, M., \&Yı1dız, C. (2009). Revision of bloom taxonomy: A general overview. Elementry Online, 8(3), 1-7.

Lai, H. C., Chang, C.Y., Shiane, L. W., Fan, Y. L., \& Wu, Y.T. (2013). The implementation of mobile learning in outdoor education: Application of QR codes. British Journal of Educational Technology, 44 (2), 57-62, https://doi.org/10.1111/j.1467$\underline{\text { 8535.2012.01343.x }}$ 
Lappin, E. (1984). Outdoor education for behavior disordered students. ERIC Digest. (National Inst. 'of Education), Washington, 2-4 Date: 02.08.2018 https://files.eric.ed.gov/fulltext/ED261811.pdf

Leblebicioğlu, G. (Ed.) (2012). Elementary 7th grade science and technology teacher manual book. Ankara: Ada publisher

Lugg, A. (2007). Developing sustainability-literate citizens through outdoor learning: possibilities for outdoor education in higher education. Journal of Adventure Education and Outdoor Learning, 7(2), 97-112. https://doi.org/10.1080/14729670701609456

Merriam, S. B. (2013). Qualitative research: a guide for pattern and application (Translated by S. Turan). Ankara: Nobel Publishing (3rd Printing Translation).

Miles, B. M., \& Huberman, A. M. (1994). Qualitative data analysis (2nd ed.). London: Sage Publication.

Ministry of National Education (MoNE) (2018). Curriculum of primary science institutions science courses (3,4,5,6,7 and 8 classes). Ankara: State Books Printing House.

Mukhopadhyay, B., Datta, J. K., \& Banerjee, A. (2014). Promotion of environmental education through facilitated field study approach- a teaching model for development of conservation attitude. Indian J. Applied \& Pure Bio, 29(1), 81-86.

Neill, J. T. (2008). Enhancing life effectiveness: the impacts of outdoor education programs. Doctor of Philosophy, University of Western Sydney, Australia

Nicolson, M. (2019). Review of the story of White Hall Centre: Outdoor education across the decades by Pete McDonald. Journal of Outdoor and Environmental Education, 22(2), 159-162. https://doi.org/10.1007/s42322-019-0030-4

Ören Şaşmaz, F., \& Erduran Avc1, D. (2004). Educational play teaching science lesson is the effect on the academic achievement of the solar system and the planets. Ondokuz Mayıs University Faculty of Education Journal, 18, 67-76.

Özkan, Y. \& Pektaş, A. (2014). A research on the relationship between graduation achievement grades and KPSS scores of senior in education faculty (educational faculty example). Studies in Turkish Science, 30, 269-281.

Öztürk, G. (2009). Out-of-school education integrated with education at school. National Education Journal, 181, 131-145.

Povilaitis, V., Riley, M., DeLange, R., Verkouw, A.J., Macklin, K., \& Hodge, C.J. (2019). Instructor impacts on outdoor education participant outcomes: a systematic review. Journal of Outdoor Recreation, Education, and Leadership, 11(3), https://doi.org/10.18666/JOREL-2019-V11-I3-9581

Priest, S. (1986). Redefining outdoor education: A matter of many relationships. Journal of Environmental Education, 17(3), 13-15. (Published online: 15 Jul 2010)

Priest, S. (2010). Redefining outdoor education: A matter of many relationships. The Journal of Environmental Education, 17(3), 13-15. https://doi.org/10.1080/00958964.1986.9941413

Ramadoss, A. \& Poya-moli, G. (2011). Biodiversity conservation through environmental education for sustainable development - a case study from puducherry, India. International Electronic Journal of Environmental Education, 1(2), 97-111.

Rauch, K. (2019). Collegebound: Assessment of an outdoor orientation program. School of Education Student Capstone Theses and Dissertations. 4453. https://digitalcommons.hamline.edu/hse_all/4453

Remington, T., \& Legge, M. (2017). Outdoor education in rural primary schools in New Zealand: A narrative inquiry. Journal of Adventure Education \& Outdoor Learning, 17(1), 55-66. 
Ritzén, J. (2018). Din grönaplättibetongdjungeln (Your green spot in the concrete jungle). DagensNyheter, 4-7. doi:10.1177/1753193417735973

Sharma-Brymer, V., Brymer, E., Gray, T., \&Davids, K. (2018). Affordances guiding Forest School practice: the application of the ecological dynamics approach. Journal of Outdoor and Environmental Education, 21(103), https://doi.org/10.1007/s42322-0170004-3

Singh, K., Granville, M., \& Dika, S. (2002). Mathematics and science achievement: effects of motivation, interest, and academic engagement. The Journal of Educational Research, 95(6), 323-332. https://doi.org/10.1080/00220670209596607

Smith, E. F., Gidlow, B., \& Steel, G. (2012). Engaging adolescent participants in academic research: the use of photo-elicitation interviews to evaluate school-based outdoor education programmes. Qualitative Research, 12(4), 367-387. https://doi.org/10.1177/1468794112443473

Stana, I., \& Humberstonea, B. (2011). An ethnography of the outdoor classroom - how teachers manage risk in the outdoors. Ethnography and Education, 6(2), 213-228.

Stanišića, J., \& Maksića, S. (2014). Environmental education in Serbian primary schools:challenges and changes in curriculum, pedagogy, and teacher training. The Journal of Environmental Education, 45(2), 118-131.

Tatar, N., \& Bağrıyanık, K. E. (2012). Views of science and technology teachers on schoolaged teaching. Elementary Online, 11 (4), 883-896.

Teyfur, E. (2008). Primary education 4-7. evaluation of the academic success of grade students and their impact on the environmental attitudes of environmental club studies. Ege University Faculty of Education, Access date: 02.08.2018. https://www.pegem.net/akademi/kongrebildiri_detay.aspx?id=101393

Thomas, G. (2019). Effective teaching and learning strategies in outdoor education: findings from two residential programmes based in Australia. Journal of Adventure Education and Outdoor Learning, 19(3), 242-255. https://doi.org/10.1080/14729679.2018.1519450

Thomas, G. J. (2015). Signature pedagogies in outdoor education. Asia-Pacific journal of health. Sport and Physical Education, 6(2), 113-126.

Tsai, J.T. (2006). The identification of the components for an outdoor education curriculum in Taiwan. PhD Thesis, Indiana University, USA.

Uhls, Y. T., Michikyan, M Morris, Ü., Garcia, D., Küçük, G. W., Zgourou, E., \& Greenfield, P. M. (2014). Five days at outdoor education camp without screens improves preteen skills with nonverbal emotion cues. Computers in Human Behavior, 39, 387-392. https://doi.org/10.1016/j.chb.2014.05.036

Yaşin, İ. (2012). The expectations from outdoor lesson activities of teacher and students participating outdoor lesson activities in second grade primary education and secondary education (example of the province of Yozgat). Unpublished Master's Thesis, Gazi University Institute of Educational Sciences, Ankara

Yıldırım, A., \& Şimşek, H. (2013). Sosyal bilimlerde nitel araştırma yöntemleri (Qualitative research methods in the social sciences). Ankara: Seçkin Publications.

Zwick, T. T., \& Miller, K. W. (1996). A Comparison of integrated outdoor education activities and traditional science learning with American Indian students. Journal of American Indian Education, 35(2), 1-9. https://www.jstor.org/stable/24398312 